\title{
Production of Bioethanol at High Temperature from Tari
}

\author{
Ali Azam Talukder 1,2,3*, Sirajul Islam Sujon², Muhammad Maqsud Hossain², \\ Donald James Gomes, ${ }^{4}$ Mamoru Yamada ${ }^{3}$ \\ ${ }^{1}$ Department of Microbiology, Jahangirnagar University, Dhaka, Bangladesh \\ ${ }^{2}$ Department of Microbiology, North South University, Dhaka, Bangladesh \\ ${ }^{3}$ Department of Biological Chemistry, Yamaguchi University, Yamaguchi, Japan \\ ${ }^{4}$ Department of Microbiology, Dhaka University, Dhaka, Bangladesh \\ Email: ${ }^{*}$ aat@juniv.edu, tunubj@yahoo.com
}

Received 10 April 2015; accepted 11 May 2015; published 14 May 2015

Copyright (C) 2015 by authors and Scientific Research Publishing Inc.

This work is licensed under the Creative Commons Attribution International License (CC BY).

http://creativecommons.org/licenses/by/4.0/

c) (i) Open Access

\section{Abstract}

Many microorganisms can tolerate high-temperature ranges from $37^{\circ} \mathrm{C}-45^{\circ} \mathrm{C}$ are called thermotolerant microorganisms. Eighteen such isolates containing various microorganisms were collected from the natural fermented products of Bangladesh in summer for bioethanol production. Cultural, morphological, physiological, biochemical and genetical analysis were carried out under various physiological conditions. Among them, two thermotolerant strains Tari-6, isolated from the Tari (an overnight natural fermented palm juice at around $33^{\circ} \mathrm{C}-40^{\circ} \mathrm{C}$ ) and Pvt-1, isolated from the Pantavat (an overnight natural fermented rice soaked with tap water at around $35^{\circ} \mathrm{C}$ $37^{\circ} \mathrm{C}$ ), produced high amount of bioethanol, $7.5 \%(\mathrm{v} / \mathrm{v})$ and $6.5 \%(\mathrm{v} / \mathrm{v})$, respectively at $37^{\circ} \mathrm{C}$. Furthermore, a partial 26S rDNA sequencing results confirmed that the Tari-6 and Pvt-1 encoded Pichia galeiformi and Pichia guilliermondii, respectively, and later one could grow well in media containing Xylose. Our results conclude that these two yeast strains are the potential candidates for bioethanol production.

\section{Keywords}

Tari, Pantavat, Bioethanol, Thermotolerant Microorganisms, Fermentation

\section{Introduction}

The production of pure ethanol apparently began in the $12-14^{\text {th }}$ century along with improvements in the art of

"Corresponding author. 
distillation permitting the condensation of vapors of lower boiling liquids. During the middle ages, alcohol was not only used for the production or as a constituent of medical drugs, but also for the manufacture of painting pigments and other chemical industries [1]. It was only in the $19^{\text {th }}$ century that this trade became an industry with enormous production, due to economic improvements of the distilling process [2]. Nowadays, ethanol is an important industrial chemical with emerging potential as a biofuel to replace vanishing fossil fuels [3]. The use of fossil fuel produces various toxic gases which cause environmental problems. Therefore, the issues of global warming and energy crisis, which are created by using fossil fuels are two major challenges in the fast growing world [1] [4]. Biofuels are one of the main renewable sources, which can contribute to overcome these problems [5]. It has been dubbed a future fuel. It can be blended with gasoline to reduce the emission of $\mathrm{CO}_{2}, \mathrm{NO}_{2}$ and hydrocarbons after combustion relative to that of gasoline alone [6].

In spite the various advantages of biofuel as a fuel the economic competitiveness with gasoline still remains an issue. To overcome this matter the use of cheap raw materials for the production of biofuel is one of the most promising methods. In this regard, numerous attempts to produce biofuel from various cheap and renewable resources such as from rice hulls, sugar cane leaves, bagasses, microalgae, sorghum, straw, industrial waste, industrial, urban and agriculture residues and corn etc have been reported [7] [8]. These important sources contain sufficient amount of carbohydrates, which can be used for biofuel production. Two biological processes are needed for biofuel production. One is saccharification that requires various enzymes, is the key step for sugar production and the other one is through fermentation [9]. Many microorganisms including yeast and bacteria convert the sugar and glucose to biofuel. However, there are some limitations in using various microorganisms for this resource because of the fact that the strains used for fermentation are mesophilic microorganisms which need extra operation cost and have some risk of contamination during bioethanol production [10]-[12].

In this study, we have tried to identify some thermotolerant microorganisms from the natural fermented sources of Bangladesh for bioethanol production. There are several potential benefits of thermotolerant microorganisms specially yeast for using in the production of industrial bioethanol which are as follows: thermotolerant yeast exhibits rapid metabolic activity and a high fermentation rate with high product output [13]. The viscosity of the fermentation broth decreases with increasing temperature [14] [15]. Therefore, the energy required to maintain proper agitation of the growth media is reduced [2] [16]. The metabolic activity of microbes and frictional effects of agitation serves to generate large amounts of heat [17]. Thus, additional energy to maintain the vessels at the desired temperature as well as the cooling requirements after sterilization is reduced. Moreover, the chances of contaminations were also minimized [18] [19].

Here, we have collected 18-isolates from the various locations of Bangladesh in summer 2010 where temperatures raised from $35^{\circ} \mathrm{C}$ to $40^{\circ} \mathrm{C}$ or above. Collected samples were characterized morphologically, physiologically, biochemically and genetically. Among them, 2-strains isolated from the Tari and Pantavat encoded Pichia galeiformis and Pichia guilliermondii, respectively, produced high amount of bioethanol under the conditions we employed here.

\section{Materials and Methods}

\subsection{Sample Collection}

Microbial samples were collected from the various sources and locations from Bangladesh in summer where temperatures fluctuate between $35^{\circ} \mathrm{C}-40^{\circ} \mathrm{C}$. Our targeted sample collection sites were Tari (an overnight natural fermented palm (Phoenyx robusta) juice at around $35^{\circ} \mathrm{C}-40^{\circ} \mathrm{C}$ ), Pantavat (Pvt) (an overnight natural fermented rice in tap water at around $35^{\circ} \mathrm{C}-38^{\circ} \mathrm{C}$ ), Sugarcane juice (Scj) from the street and decomposed food materials (Dfm) from markets. Other sources can also be considered where necessary.

Tari is a local name of sap of palm tree (Phoenyx robusta), which was collected in a pot from the xyleme tissue. This pot can carry about 15 - 20 liters of palm juice collected in $12 \mathrm{~h}$. Three samples (upper, middle and bottom layers) were collected separately from the pot by using sterilized glass pipettes and the Tari mixed sample was collected after mixed upper, middle and bottom layer sample by mixer and then collected sample from the middle position of the pot.

Total 18-samples containing various thermotolerant microorganisms were collected for several analysis shown respective section below. Among them 6from Tari (Tari-1,Tari-2,Tari-3, Tari-4, Tari-5, and Tari-6); 2 from Pantavat (Pvf-1 and Pvf-2); 6 from Sugarcane juice (Scj-1, Scj-2, Scj-3, Scj-4, Scj-5 and Scj-6and 4 from Decomposed food materials (Dfm-1, Dfm-2, Dfm-3 and Dfm-4) were collected and preserved short time where 
necessary. Cultural, morphological, physiological, biochemical and genetical analysis were carried out under various physiological conditions. In addition, here we introduce promising one thermotolerant yeast, Klu (Kluyueromyces marxinus) as an internal thermotolerant control strain, which was gifted by Professor Mamoru Yamada, Yamaguchi University, Japan.

\subsection{Collection and Isolation of Thermotolerant Microorganisms}

Sample collection was carried out from April to June, 2010 in summer where temperatures fluctuate from 33 $40^{\circ} \mathrm{C}$ by an enrichment technique in media containing sugar cane juice (8\% total sugars), $0.05 \%\left(\mathrm{NH}_{4}\right)_{2} \mathrm{SO}_{4}$ and $4 \%(\mathrm{v} / \mathrm{v})$ ethanol at $\mathrm{pH} 4.5$ [14]. After inoculation, cultures were incubated for 3 days in a rotary shaker at a predetermined temperature with shaking speed of $160 \mathrm{rpm}$. Enriched cultures were then streaked on agar plates containing the same medium and inoculated at various temperatures. Purified yeast cultures were kept on YPD agar plates and slants ( $1 \%$ yeast extract, $2 \%$ glucose, $2 \%$ peptone and $2 \%$ agar) and then stored at $4{ }^{\circ} \mathrm{C}$ until use. Thermotolerant yeast strains were selected based on their growth performances at various temperatures like $37^{\circ} \mathrm{C}, 40^{\circ} \mathrm{C}$ and $42^{\circ} \mathrm{C}$ and other stresses [20]. Cultures were then collected and screened further for their ethanol production efficiency on above temperatures.

\subsection{Screening Thermotolerant Microorganisms}

Collected microorganisms were used for isolation/screening purposes. In order to find out their optimum growth environment, experiments were carried out in both solid and liquid medium under different physiological conditions. To understand the thermotolerant nature of the isolates they were grown on ranges of temperature $\left(35^{\circ} \mathrm{C}\right.$ $45^{\circ} \mathrm{C}$ ). Microscopic studies were used to identify strain morphologically, after exposed to various physiological conditions during their growth and multiplication [21]. Furthermore, sequencing of 26S rDNA (Yeast D1/D2 region) was carried out further for identification/screening microorganisms from the large populations.

\subsection{Microscopic Observation}

Thermotolerant microbes were grown in both the YPD solid and the liquid medium in Pettri-plates and flasks, respectively, under various physiological conditions. Cells were harvested by mild centrifugation (5000 rpm for $5 \mathrm{~min}$ ) and then prepared for microscopic study. In brief, cells were washed, fixed and stained with $5 \mu \mathrm{g} / \mathrm{ml}$ DAPI (nucleoid specific dye, which binds tightly where nucleic acids are available and stained in blue color). Fluorescent and phase contrast microscope was used for characterization thermotolerant yeasts morphologically as described previously [22].

\subsection{Selection of Thermotolerant Microorganisms for Bioethanol Production}

Selection microorganisms for high ethanol production were conducted independently under various medium temperatures, pHs, and carbon sources as described in the results section. Inoculums were prepared by transferring one loop full of $24 \mathrm{~h}$ culture grown on a plate of YPD agar to an Erlenmeyer flask containing $50 \mathrm{ml}$ of a sugar cane juice medium as described above. The inoculums were transferred at the rate of $1 \%$ to the screening medium, followed by incubation on a rotary shaker at various temperatures ranging from $30^{\circ} \mathrm{C}$ to $42^{\circ} \mathrm{C}$ in $250 \mathrm{ml}$ Erlenmeyer flasks containing $100 \mathrm{ml}$ of a basal sugar cane juice medium composed of sugar cane juice supplemented with glucose up to $18 \%$ total sugars and $0.05 \%\left(\mathrm{NH}_{4}\right)_{2} \mathrm{SO}_{4}$ [14]. Glucose concentrations were varied from $16 \%$ to $22 \%(\mathrm{v} / \mathrm{v})$, differing by $5 \%(\mathrm{v} / \mathrm{v})$ from one flask to the other.

\subsection{Bioethanol Fermentation}

One loop-full of yeast colony was taken from YPD Agar plate of $24 \mathrm{~h}$ culture into sterile $10 \mathrm{ml}$ distilled water in test tube, which was shaken well by vortex mixer to dispense the cells into a homogenous suspension. One millilitre of suspension (about $10^{8}$ viable cells) was inoculated to $100 \mathrm{ml}$ Basal media in $250 \mathrm{ml}$ conical flask on a $160 \mathrm{rpm}$ rotary shaker for $24-72 \mathrm{~h}$ [14]. The yeast count was determined by using Neubauer counting chamber (Japan). The standard concentration of the inoculums $\left(10^{8}\right.$ cells $\left./ \mathrm{ml}\right)$ was prepared by the appropriate dilution with sterile distilled water. 


\subsection{Bioethanol Estimation}

Ethanol produced in the fermentation medium was estimated by titration (potassium dichromate oxidation) method. Fresh potassium dichromate (33.882 g/l), ferrous ammonium sulphate (135.5 g/l) and diphenylamine ( $0.5 \mathrm{~g} / 100 \mathrm{ml}$ concentrated $\mathrm{H}_{2} \mathrm{SO}_{4}$ ) solutions were used as reagent for estimation of ethanol concentration. The fermented sample was diluted ten times with distilled water. Ten millilitre of the diluted sample was distilled against $\mathrm{K}_{2} \mathrm{Cr}_{2} \mathrm{O}_{7}(10 \mathrm{ml})$ containing concentrated $\mathrm{H}_{2} \mathrm{SO}_{4}(5-6 \mathrm{ml})$. Then distilled product was titrated against freshly prepared ferrous ammonium sulphate solution with diphenylamine as an indicator. Appearance of green color indicated the end point of the titration. Burette reading (amount ferrous ammonium sulphate) will be recorded to calculate the amount (in percentage) of bioethanol present in the sample.

\subsection{DNA Sequencing}

Overnight cultures of different strain background were collected for DNA extraction, purification, PCR and sequence purposes. The cells were washed once with distilled water, resuspended with $2 \mathrm{ml}$ of distilled water. One $\mathrm{ml}$ of cell suspension was collected onto the $1.5 \mathrm{ml}$ micro-centrifuge tube. After centrifugation, excess water was removed from the micro-centrifuge tube, and the cells were stored in a freezer $\left(-20^{\circ} \mathrm{C}\right)$ until use. Genomic DNA was separated and purified by using DNA extraction kits (Takara, Japan). The yeast D1/D2 domain was amplified by PCR with forward primer and the reverse primers of NL-1 and NL-4, respectively [(forward Primer NL-1: (5'-GCATATCAATAAGCGGAGGAAAAG-3'), (reverse Primer NL-4:

(5’-GGTCCGTGTTTCAAGACGG-3’)], [23]. The PCR product was checked by Agarose gel electrophoresis, purified using the ABI BigDye terminator Cyclo sequencing Kit Version. 3.1 (Applied Biosystem, California, USA) with the external primer IL-1 and IL-4 [24]. The sequences were determined with PRISON BIO genetic Analyzer (Applied Biosystems, California, USA) according to the instructions of the manufacturer. The sequence compared pair-wise using the BLAST homology search.

\section{Result and Discussion}

\subsection{Thermotolerant Microorganisms Collected from the Various Natural Fermented Sources of Bangladesh}

Thermotolarent microorganisms were collected from various natural fermented sources of Bangladesh in summer where temperatures fluctuate from $33^{\circ} \mathrm{C}-40^{\circ} \mathrm{C}$. In this period many natural fermented products are available. Sample was collected from April to June 2010 and the detail procedure for sample collection was described in the Materials and Methods. We have collected 18 samples. Among them six were collected from Tari (Tari-1, Tari-2, Tari-3, Tari-4, Tari-5, Tari-6); two were isolated from Pantavat (Pvt-1 and Pvt-2); six were collected from Sugarcane Juice from the street (Scj-1, Scj-2, Scj-3, Scj-4, Scj-5, Scj-6); and four were isolated from Decomposed food materials (Dfm-1, Dfm-2, Dfm-3 and Dfm-4). Various fermented samples are shown in Figure 1 and the detail sample descriptions (name, sources, collection site, time, temperatures etc) are mentioned in Table 1. Collected samples were started to screen morphologically, physiologically, biologically and genetically to cheek their abilities to produce bioethanol. Results are shown in respective section below.

\subsection{Morphological Characterization of Thermotolerant Yeasts}

Collected samples were grown in various conditions including medium carbon sources, temperatures and pHs. The detail procedures for morphological characterizations are described in the Materials and Methods. Morphological study was carried out by using fluorescent microscope, after various cells was grown to YPD liquid medium. Collected cells were washed, fixed and stained with DAPI. A typical Fluorescence and phase contrast microscopic images of various isolates are shown in Figure 2. Among them, Pvt-1, Scj-1, Pvt-2 and Tari-6 showed both fluorescent and phase contrast images (Figure 2, top left and right panel). On the otherhand, only phase contrast images are shown in case of Tari mixed sample and one internal control, Klu. Among the 5-different strains analyzed here, we could observe different shapes and sizes of cells as well as their structures and organizations of intact cell-nucleoids. Because, florescence dye DAPI bind nucleoid area onto the cell where nucleic acid and several DNA-binding proteins are associated and make compact structure called nucleoid. On the other hand, phase-contrast image detects cell shape and size only. These results indicate that our isolates covered var- 


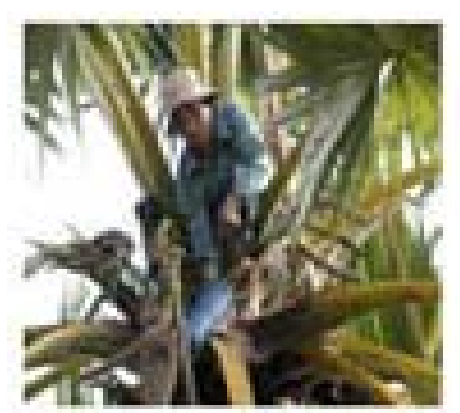

(a)

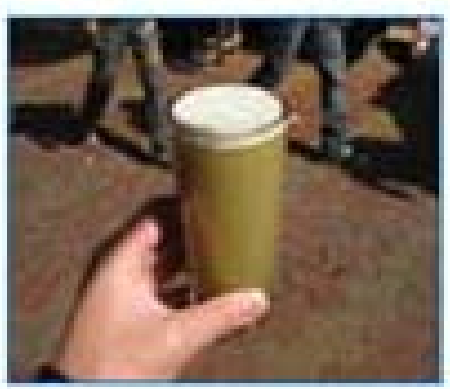

(d)

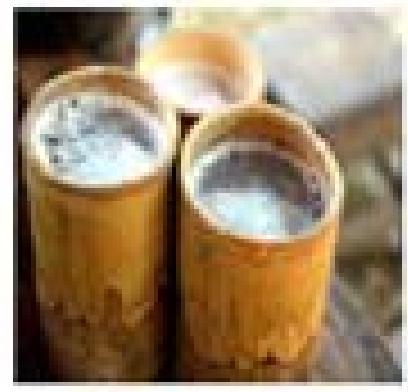

(b)

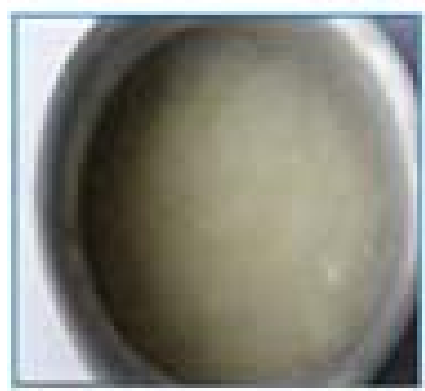

(e)

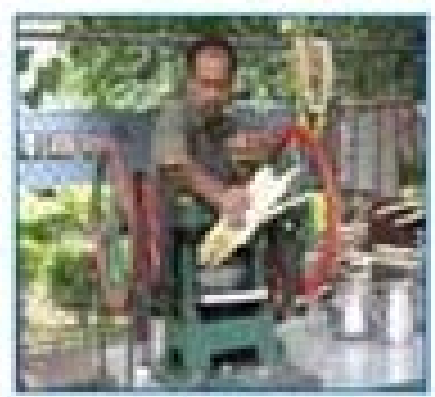

(c)

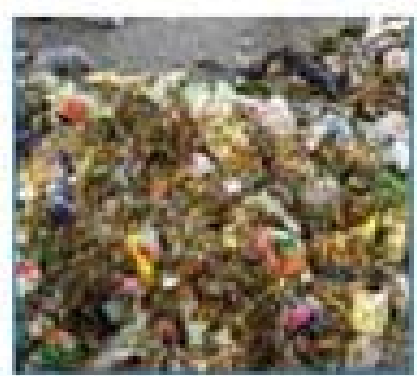

(f)

Figure 1. Various natural fermented samples were collected for bioethanol production. (a) Collecting process of Tari (palm juice); (b) Tari in a natural bamboo pot for marketing; (c) Sugarcane juice extraction process in the street; (d) Sugarcane juice ready for drink; (e) Pantavat in a rice dish; and (f) Decomposed food materials. Sample description was discussed in detail in the Materials and Methods.

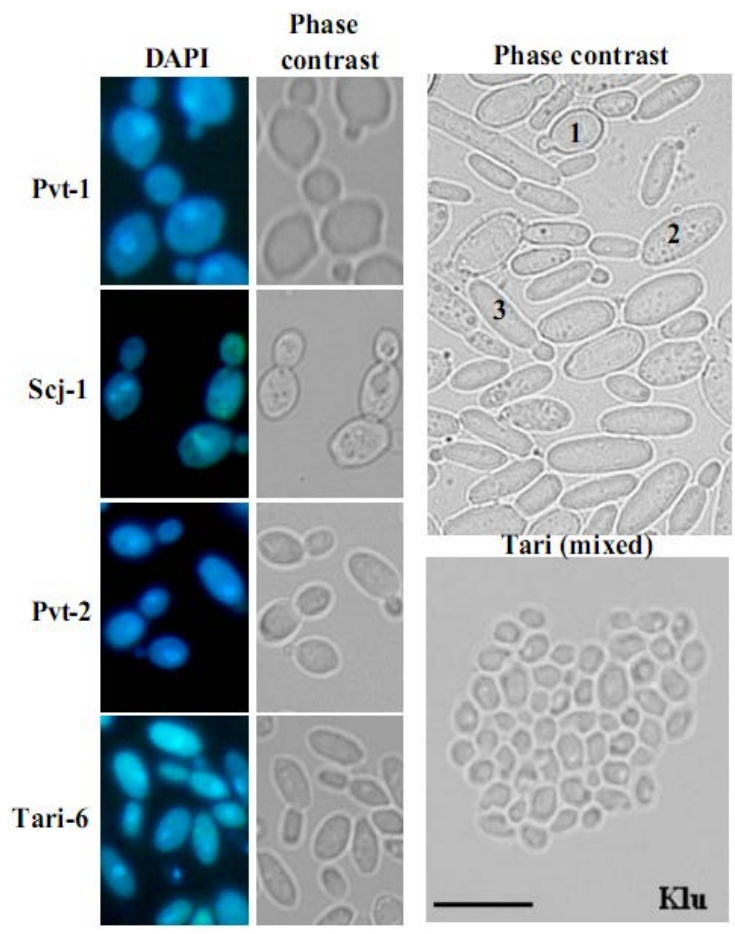

Figure 2. Fluorescence microscopic images of thermotolerant yeasts isolated from the various natural fermented sources of Bangladesh. Yeast cells were grown in YPD medium at $42^{\circ} \mathrm{C}$ for 24 hours at $100 \mathrm{rpm}$, collected, fixed and stained with DAPI and examined by Fluorescence microscope. DAPI images (blue color) represented the location of nucleoid onto the cell, while phase contrast images showed the cell shapes and sizes. Scale bar represents $15 \mu \mathrm{M}$. 
Table 1. Various isolates containing different thermotolerant microorganisms were collected from the various natural fermented sources of Bangladesh in summer.

\begin{tabular}{|c|c|}
\hline Strain ID & Sample description, collection site/time/date/temperature \\
\hline 1. Tari-1 & Upper layer, Dumni, North site of Dhaka/1.00 pm/4 $4^{\text {th }}$ June $2010 / 40^{\circ} \mathrm{C}$. \\
\hline 2. Tari-2 & Middle layer, Dumni, $1.00 \mathrm{pm}, 4^{\text {th }}$ June $2010 / 40^{\circ} \mathrm{C}$. \\
\hline 3. Tari-3 & Bottom layer, Dumni, $1.00 \mathrm{pm}, 4^{\text {th }}$ June $2010 / 40^{\circ} \mathrm{C}$. \\
\hline 4. Tari-4 & Upper layer, Kamarkhanda, Bangladesh, 3.00 pm, $27^{\text {th }}$ June $2010 / 37^{\circ} \mathrm{C}$. \\
\hline 5. Tari-5 & Middle layer, Kamarkhanda, Bangladesh, 3.00 pm, $27^{\text {th }}$ June $2010 / 37^{\circ} \mathrm{C}$. \\
\hline 6. Tari-6 & Bottom layer, Kamarkhanda, Bangladesh, $3.00 \mathrm{pm}, 27^{\text {th }}$ June $2010 / 37^{\circ} \mathrm{C}$. \\
\hline 7. Pvt-1 & Pantavat, Dhanmmondi, Dhaka/11 am, $23^{\text {th }}$ April 2010/around 35-37 ${ }^{\circ} \mathrm{C}$. \\
\hline 8. Pvt-2 & Pantavat, Savar, Dhaka/12 noon, $24^{\text {th }}$ April 2010/around $35-37^{\circ} \mathrm{C}$. \\
\hline 9. Scj-1 & Sugarcane juice, Bisho-road, Dhaka/11.00 am, $12^{\text {th }}$ April $2010 / 35^{\circ} \mathrm{C}$. \\
\hline 10. Scj-2 & Sugarcane juice, Banani, Dhaka/12.00 noon, $12^{\text {th }}$ April $2010 / 37^{\circ} \mathrm{C}$ \\
\hline 11. Scj-3 & Sugarcane juice, Farm gate, Dhaka/1.00 pm, $12^{\text {th }}$ April $2010 / 38^{\circ} \mathrm{C}$ \\
\hline 12. Scj-4 & Sugarcane juice, New marker, Dhaka/1.00 pm, $14^{\text {th }}$ April $2010 / 37^{\circ} \mathrm{C}$ \\
\hline 13. Scj-5 & Sugarcane juice, Shahbag, Dhaka/2.00 pm, $14^{\text {th }}$ April $2010 / 38^{\circ} \mathrm{C}$ \\
\hline 14. Scj-6 & Sugarcane juice, Paltan, Dhaka/3.00 pm, $14^{\text {th }}$ April $2010 / 37^{\circ} \mathrm{C}$. \\
\hline 15. Dfm-1 & Dfm, New-market, Rajshahi, Bangladesh/3.00 pm, $19^{\text {th }}$ May $2010 / 38^{\circ} \mathrm{C}$. \\
\hline 16. Dfm-2 & Dfm, New market, Dhaka, Bangladesh $/ 1.00 \mathrm{pm}, 20^{\text {th }}$ May $2010 / 36^{\circ} \mathrm{C}$. \\
\hline 17. Dfm-3 & Dfm, New marker, Chittagang, Bangladesh $/ 1.00 \mathrm{pm}, 21^{\text {th }}$ May $2010 / 37^{\circ} \mathrm{C}$. \\
\hline 18. Dfm-4 & Dfm, New market, Pabna, Bangladesh $/ 3.00$ pm, $24^{\text {rd }}$ May $2010 / 37^{\circ} \mathrm{C}$. \\
\hline Klu & Kluyueromyces marxinus, an internal thermotolerant control strain. \\
\hline
\end{tabular}

ious types of yeast cells. At least 3-different types of yeast cells were found in Tari mixed sample (represented by numbers, 1, 2 and 3 in Figure 2 top right panel), indicate that these strains might be involved in succession process which may converted alcohol to other components like acetic acid. Because, when naturally fermented Tari kept at relatively longtime its taste gradually charges from sweet to sour.

\subsection{Physiological Characterization of Thermotolerant Yeasts}

Various physiological parameters for growth of at least 7-thermotolerant yeasts were recorded here. Among them, different carbon sources, temperatures and pHs were checked and the results are shown below. Three carbon sources (Dextrose, Arabinose and Xylose) were independently added in the medium and check their sensitivity test under different tested temperatures and pHs. Thermotolerant yeasts were grown in solid media containing either YPD or YPX and their growth was recorded after incubating at various mentioned temperatures and pHs for 2 days are shown in Figure 3. The shapes, sizes, textures, colors and colony surfaces were measures under identical condition. All strains could grow well in the medium supplemented by Dextrose and Arabinose (data not shown). However, when we added Xylose instead of either Dextrose or Arabinose, only strain Pvt-1 isolated from Pantavat could grow well (Figure 3). This result concluded that the strain isolated from Pantavat is one of the potential candidates for bioethanol production, which may use Xylose as a sole carbon source at high temperature fermentation [10] [25] [26].

Furthermore, medium growth temperatures effect was monitored in temperatures ranges from $23^{\circ} \mathrm{C}-42^{\circ} \mathrm{C}$. Two-carbon sources (YPD and YPX) were applied in solid agar plates. Among the result of various temperatures sensitivity test which are shown in Table 2, comparatively slow and rapid growth was observed at 23 and $37^{\circ} \mathrm{C}$, respectively. This result again concludes that the all yeast stains were grown well at $30^{\circ} \mathrm{C}-42^{\circ} \mathrm{C}$ in $\mathrm{YPD}$ 
medium. However, in YPX medium no growth was seen except Pvt-1 strain as mentioned before. Under the condition we employed here, maximum growth was observed in both carbon sources at $37^{\circ} \mathrm{C}$ in Pvt- 1 strain, demonstrates that this strain may have ferment Xylose in addition to other carbon sources to produce bioethanol [27] [28].

\subsection{Biochemical Characterization of Thermotolerant Microorganisms}

The optimum temperature, which gave the highest cell dry weight, was at $37^{\circ} \mathrm{C}$ and temperature higher than $40^{\circ} \mathrm{C}$, the growth of maximum yeasts was decreased (Table 2). Bioethanol fermentation was investigated at temperature higher than optimum temperature as shown in Figure 4 top panel. Because, yeast currently used for
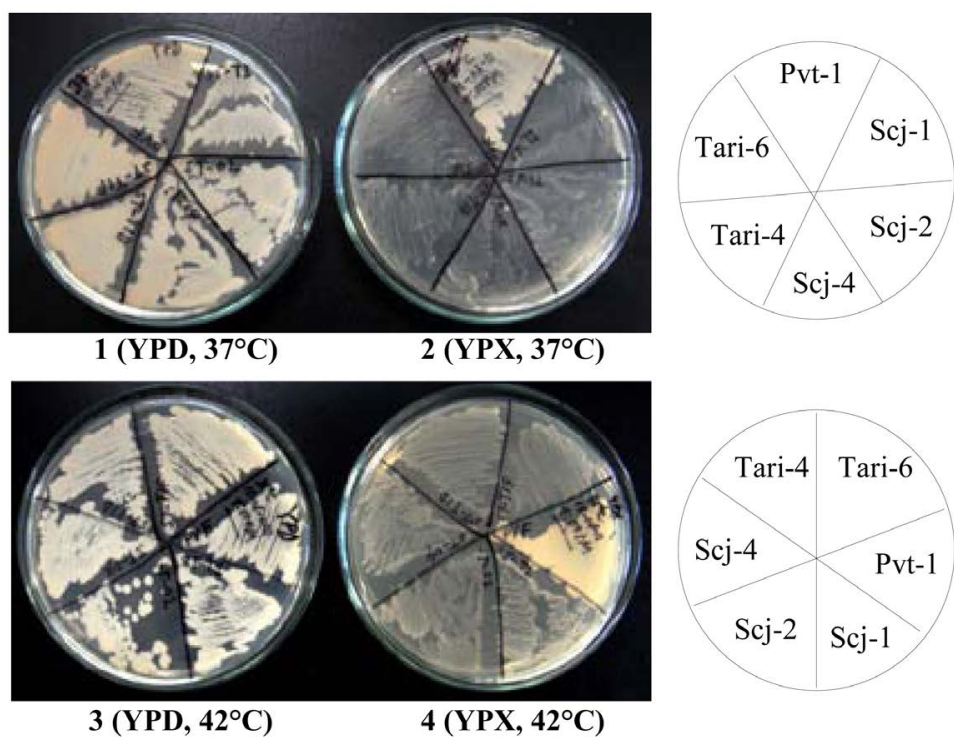

Figure 3. Substrate specific growth of thermotolerant yeasts isolated from the various natural fermented sources of Bangladesh. Various yeast cells were grown either in YPD (left) and in YPX (right) solid agar plates are shown. Here, Top plate 1 and 2 represent 2-days old YPD and YPX agar plates, respectively, which were grown at $37^{\circ} \mathrm{C}$, while bottom plate 3 and 4 represent 2-days old YPD and YPX agar plates, respectively, which were grown at $42^{\circ} \mathrm{C}$. It is clear that the strain Pvt-1 (Pichia guilliermondii) isolated from the Pantavat could grow well in both YPD and YPX medium, among the 6thermotolerant Yeasts were screened.

Table 2. Screening thermotolerant microbes under various growth temperatures and carbon sources.

\begin{tabular}{|c|c|c|c|c|c|c|c|c|}
\hline Strain & $\begin{array}{l}\text { YPD } \\
23^{\circ} \mathrm{C}\end{array}$ & $\begin{array}{l}\text { YPD } \\
\mathbf{3 0}^{\circ} \mathrm{C}\end{array}$ & $\begin{array}{l}\text { YPD } \\
37^{\circ} \mathrm{C}\end{array}$ & $\begin{array}{l}\text { YPD } \\
42^{\circ} \mathrm{C}\end{array}$ & $\begin{array}{l}\text { YPX } \\
23^{\circ} \mathrm{C}\end{array}$ & $\begin{array}{l}\text { YPX } \\
\mathbf{3 0}^{\circ} \mathrm{C}\end{array}$ & $\begin{array}{l}\text { YPX } \\
\mathbf{3 7}^{\circ} \mathbf{C}\end{array}$ & $\begin{array}{l}\text { YPX } \\
42^{\circ} \mathrm{C}\end{array}$ \\
\hline Scj-1 & ++ & +++ & ++++ & +++ & +- & +- & +- & +- \\
\hline Scj-2 & ++ & +++ & ++++ & +++ & +- & +- & +- & +- \\
\hline Scj-4 & ++ & +++ & ++++ & +++ & +- & +- & +- & +- \\
\hline Tari-4 & ++ & +++ & ++++ & +++ & +- & +- & +- & +- \\
\hline Tari-6 & ++ & +++ & ++++ & +++ & +- & +- & +- & +- \\
\hline Pvt-1 & ++ & ++++ & ++++ & +++ & ++ & ++++ & ++++ & +++ \\
\hline Klu & ++ & +++ & ++++ & ++++ & +- & +- & +- & +- \\
\hline
\end{tabular}

Various trains containing different microbes were grown to either YPD or YPX agar plate for 2-days at different mentioned temperatures. Here, YPD = Yeast-Peptone-Dextrose media; YPX = Yeast-Peptone-Xylose media; ++++ = Excellent Growth; +++ = Good Growth; ++ = Slow Growth, and += Very Slow Growth or No Growth. Experiment was carried at least three times. 
industrial fermentation is rapidly inactivated at $33^{\circ} \mathrm{C}-35^{\circ} \mathrm{C}$ [29]. Significant cooling costs would be eliminated, especially during the summer or in tropical countries, with fermenting temperatures of $40^{\circ} \mathrm{C}$ and above. Only a few screening surveys have been carried out for the ability of yeasts to grow in a flask at or above $40^{\circ} \mathrm{C}$ [14] [19] [21]. Cells were grown to the YPD medium for 3-days in different mentioned temperatures. Cells were collected and bioethanol production rate was measured as described in the Materials and Methods. The minimum 3.5 to maximum $7.5 \% \mathrm{v} / \mathrm{v}$ bioethanol were estimated from various tested temperatures as shown in Figure 4. Among the different strains were examined here, Tari-6 gave the highest bioethanol at various tested temperatures. The highest $7.5 \%(\mathrm{v} / \mathrm{v})$ and the lowest $6.0 \%(\mathrm{v} / \mathrm{v})$ bioethanol were estimated from the strain Tari 6 at $37^{\circ} \mathrm{C}$ and $42^{\circ} \mathrm{C}$, respectively. This result concludes again that the optimum cell growth correlated with the maximum production of bioethanol at $37^{\circ} \mathrm{C}$ as suggested previously [11] [30].

Medium $\mathrm{pH}$ is an important determinant for bioethanol production. Yeast cells can increase fermentation in acidic condition [31]. Therefore, we have checked bioethanol activity after cultured cells in medium containing various $\mathrm{pHs}$, which was adjusted by adding either $1 \mathrm{~N} \mathrm{HCl}$ or $1 \mathrm{~N} \mathrm{NaOH}$ according to the protocol developed by [32]. Cell growth rate was increased along with the $\mathrm{pH}$ level increase from 4.0 to above (data not shown). No more significant different was observed on the growth rate at $\mathrm{pH} 4.5$ to 7.0, but beyond that the growth rates were decreased (data not shown). However, medium pHs had an important impact on bioethanol production. Maximum and minimum bioethanol production was observed when medium pHs was 4.5 and 7.0, respectively, as shown in Figure 4 bottom panel. Different samples have different rates of bioethanol production. Samples isolated from the Tari-6 and Sugarcane juice (Scj-4) produce maximum up to $7.0 \%$ and minimum up to 3.0\%, bioethanol, respectively, when the medium $\mathrm{pH}$ was 4.5 (Figure 4).

\subsection{Genetical Characterization of Thermotolerant Yeast}

Finally, tested yeast strains were analyzed genetically using 26S rDNA sequencing in order to know their genetical identity, especially in genus level. Sample preparation, PCR amplification and DNA sequencing procedures

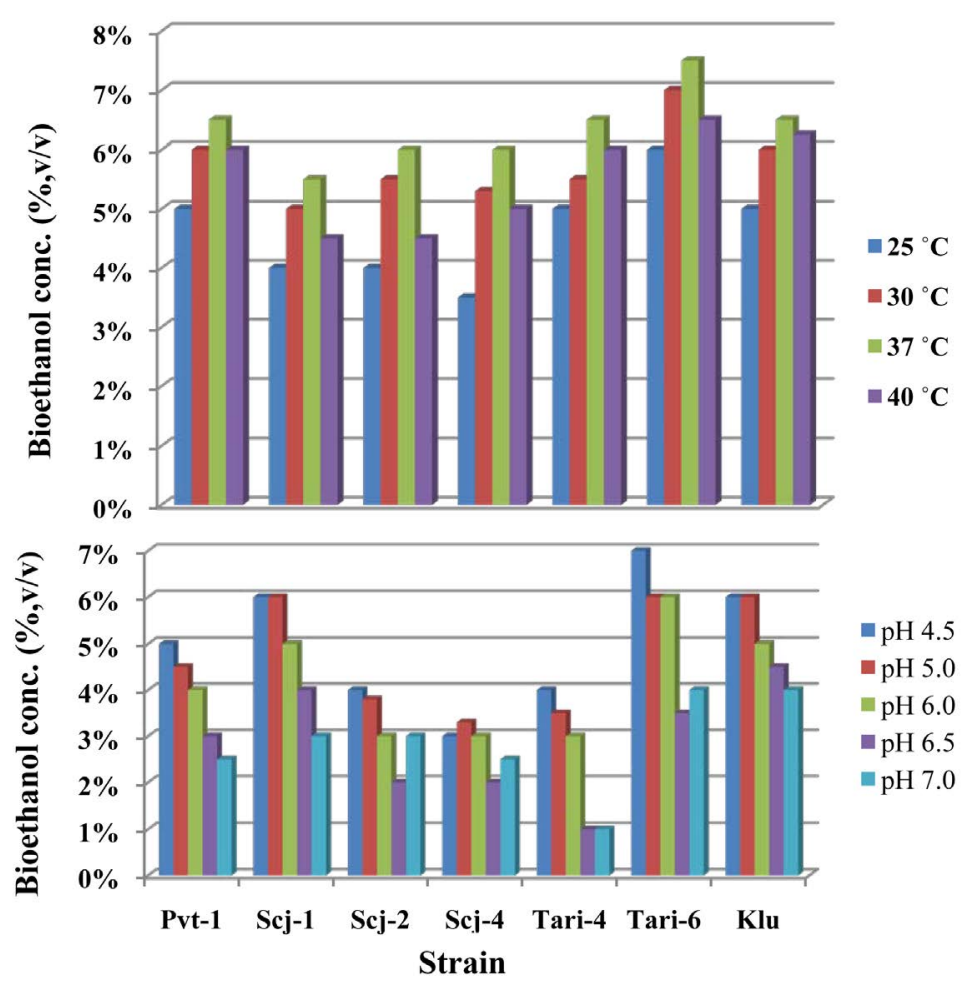

Figure 4. Effect of growth temperatures and medium pHs on bioethanol production. Cells were grown under various growth temperatures (top) and medium pHs (bottom) and their bioethanol content were measured. Procedure for sample selection, culture and harvested for bioethanol production are shown detail in the Materials and Methods. 
were described in the Materials and Methods. Figure 5 shows the growth of 3-starins in YPD medium (top left) and Agarose gel electrophoresis patterns of 3-PCR amplified Yeast D1/D2 fragments isolated from Sugarcane juice, Tari and Pantavat (bottom left), each represents about 500 base pairs of DNA sequences. Among them, only 161 nucleotide sequences of each of 3-strains were shown in Figure 5 (right panel), which were compared with other yeast D1/D2 region from GenBank, EMBL and DDBJ databases. Results from the BLAST analysis revealed that the strain isolated from natural fermented products Pvt-1 encoded Pichia guilliermondii, Scj-1 encoded Saccharomyces cerevisiae, Tari-4 encoded Pichia kudriavzeii and Tari-6 encoded Pichia galeiformis are shown in Table 3.

\section{Conclusion}

In this study, our main target was to identify some thermotolerant microorganisms from the natural sources of Bangladesh for bioethanol production. After screening 18 samples morphologically, physiologically, biochemically and genetically (DNA sequencing), here we have concluded that the isolates from the Tari (Pichia galeiformis) and Pantavat (Pichia guilliermondii) are potential thermotolerant microorganisms produced higher

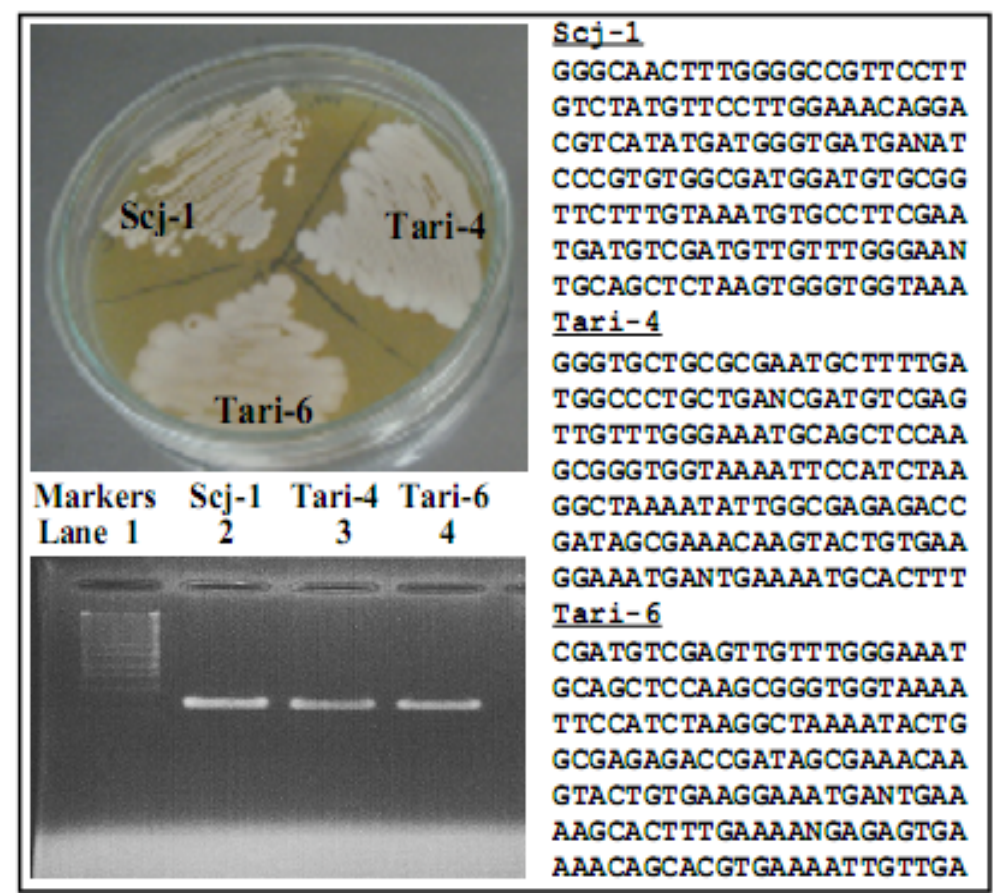

Figure 5. Partial 26S rDNA sequences of the thermotolerant yeasts isolated from the natural fermented sources of Bangladesh. Three strains Scj-1, Tari-4 and Tari-6 were grown in YPD Agar plate are shown (Top left). Agarose gel electrophoresis pattern of PCR-amplified fragments from above three-thermotolerant yeast strains D1/D2 region (Bottom left). Lane 1 represents the marker's- $\lambda$ Sty and Lane 2-4 represented various thermotolerant yeasts (Lane 2 , Scj-1 = Sugarcane juice; Lane 3, Tari-4 and Lane 4, Tari-6. Tari-4 and Tari-6 represent the upper and bottom layer of Tari sample, respectively, as shown in Table 1). Gel was stained with Ethidium Bromide and photographed. Among them, about 500bp PCR-amplified yeast D1/D2 fragment are shown. Right side showed 26S rDNA sequences (161 nucleotides) of three-yeast strains used for stain identification.

Table 3. DNA sequence information of 4-thermotolerant yeasts isolated from the natural fermented products of Bangladesh.

\begin{tabular}{ccc}
\hline Strain & Maximum Identity & Blast Search Result \\
Tari-4 & $100 \%$ & Pichia kudriavzeii \\
Tari-6 & $100 \%$ & Pichia galeiformis \\
Scj-1 & $100 \%$ & S. cerevisiae \\
Pvt-1 & $99 \%$ & Pichia guilliermondii \\
\hline
\end{tabular}


amount of bioethanol under the condition we employed here. Further research is required to establish temperature conditions and various parameters for optimum growth and production of bioethanol in laboratory scale [33].

\section{Acknowledgements}

We thank Dr. L. Noppon for discussion and help for DNA sequencing. The authors wish to thank Ministry of Education (17/10, M-15/2007/226), Bangladesh for funding of this research work and the HEQEP (W1, CP3413) for publication cost of this manuscript.

\section{References}

[1] Amin, S. (2009) Review on Biofuel Oil and Gas Production Processes from Microalgae. Energy Coverage Manage, 50, 1834-1840.

[2] Roehr, M. (2001) The Biotechnology of Ethanol: Classical and Future Applications. Wiley-VCH, Chichester, 232 p.

[3] Alfenore, S., Molina-Jouve, C., Guillouet, S.E., Uribelarrea, J.L., Goma, G. and Benbadis, L. (2002) Improving Ethanol Production and Viability of Saccharomyces cerevisiae by a Vitamin Feeding Strategy during Fed-Batch Process. Applied Microbiology and Biotechnology, 60, 67-72. http://dx.doi.org/10.1007/s00253-002-1092-7

[4] Costa, D.A., de Souza, C.J,, Costa, P.S., Rodrigues, M.Q., dos Santos, A.F., Lopes, M.R., Genier, H.L., Silveira, W.B. and Fietto, L.G. (2014) Physiological Characterization of Thermotolerant Yeast for Cellulosic Ethanol Production. Applied Microbiology and Biotechnology, 98, 3829-3840. http://dx.doi.org/10.1007/s00253-014-5580-3

[5] Prasad, S., Singh, A. and Joshi, H.C. (2007) Ethanol Is an Alternative Fuel from Agriculture, Industrial and Urban Residues. Resource on Servre Cycle, 50, 1-39. http://dx.doi.org/10.1016/j.resconrec.2006.05.007

[6] Anderson, P.J., McNeil, K. and Watson, K. (1986) High-Efficiency Carbohydrate Fermentation to Ethanol at the Temperature above $40^{\circ} \mathrm{C}$ by Kluyveromyces marxianus var. Kluyveromyces marxianus Isolated from Sugar Mills. Journal of Applied and Environmental Microbiology, 51, 1314-1320.

[7] Ha, J.H., Shah, N., Islam, M.U. and Park, J.K. (2011) Potential of the Waste from Beer Fermentation Broth for Bioethanol Production without Any Additional Enzyme, Microbial Cell and Carbohydrates. Enzyme and Microbial Technology, 49, 298-304. http://dx.doi.org/10.1016/j.enzmictec.2011.04.016

[8] Kamei, I., Hirota, Y., Mori, H., Hirai, H., Meguro, S. and Kondo, R. (2012) Direct Ethanol Production from Cellulosic Materials by the Hypersaline-Tolerant White-Rot Fungus Phlebia sp. MG-60. Bioresource Technology, 112, 137-142. http://dx.doi.org/10.1016/j.biortech.2012.02.109

[9] Satyanarayana, T. and Kunze, G. (2009) Yeast Biotechnology: Diversity and Applications. Springer Publication.

[10] Rodrussamec, N., Lertwattanesakul, N., Hirata, K., Limtong, S., Kosaka, T. and Yamada, M. (2011) Growth and Ethanol Fermentation Ability on Hexose and Pentose Sugars and Glucose Effect under Various Conditions in Thermotolerant Yeast Kluveromyces marxianus. Applied Microbiology and Biotechnology, 90, 1573-1586.

[11] Lertwattanesakul, N., Limtong, S., Rodrussamec, N., Thanonkeo, P., Tomoyuki, K. and Yamada, M. (2011) Utilization Capability of Sucrose, Raffinose and Inulin and Its Less-Sensitiveness to Glucose Repression in Thermotolerant Yeast Kluyveromyces marxianus DMKU 3-1042. AMB Express, 1, 20.

[12] Narra, M., James, J.P. and Balasubramanian, V. (2015) Simultaneous Saccharification and Fermentation of Delignified Lignocellulosic Biomass at High Solid Loadings by a Newly Isolated Thermotolerant Kluyveromyces sp. for Ethanol Production. Bioresource Technology, 179, 331-338. http://dx.doi.org/10.1016/j.biortech.2014.11.116

[13] Strobel, G.A. (2015) Bioprospecting-Fuels from Fungi. Biotechnology Letters, 37, 973-982. http://dx.doi.org/10.1007/s10529-015-1773-9

[14] Limtong, S., Sringiew, C. and Yongmanitchai, W. (2007) Production of Fuel Ethanol at High Temperature from Sugar Cane Juice by a Newly Isolated Kluyveromyces marxianus. Bioresource Technology, 98, 3367-3374. http://dx.doi.org/10.1016/j.biortech.2006.10.044

[15] Hacking, A.J., Taylor, I.W.F. and Hanas, C.M. (1984) Selection of Yeast Able to Produce Ethanol from Glucose at $40^{\circ}$ C. Applied Microbiology and Biotechnology, 19, 361-363. http://dx.doi.org/10.1007/BF00253786

[16] Stanbury, P.F., Whitaker, A. and Hall, S.J. (2003) Principal of Fermentation Technology. 2nd Edition, ButterworthHeinemann, Oxford.

[17] Arthur, H. and Watson K. (1976) Thermal Adaptation in Yeast: Growth Temperatures, Membrane Lipid, and Cytochrome Composition of Psychrophilic, Mesophilic, and Thermophilic Yeasts. Journal of Bacteriology, 128, 56-68.

[18] Sree, N.K., Sridhar, M., Rao, L.V. and Pandey, A. (1999) Ethanol Production in Solid Substrate Fermentation Using Thermotolerant Yeast. Process Biochemistry, 34, 115-119. 
[19] Murata, M., Rodrussamec, N., Suprayogi, Nakajima, Y., Lertwattanesakul, N. and Yamada, M. (2010) High-Temperature Ethanol Fermentation with Thermotolerant Microbes. Proceedings of Bangladesh Academy of Sciences, 5th Bangladesh-Japan Joint International Conference, Dhaka, 26-28 December 2010, 199-205.

[20] Della-Bianca, B.E. and Gombert, A.K. (2013) Stress Tolerance and Growth Physiology of Yeast Strains from the Brazilian Fuel Ethanol Industry. Antonie van Leeuwenhoek, 104, 1083-1095. http://dx.doi.org/10.1007/s10482-013-0030-2

[21] D’Amore, T., Celotto G., Russel, I. and Stewart, G.G. (1989) Selection and Optimization of Yeast Suitable for Ethanol Production at $40^{\circ} \mathrm{C}$. Enzyme and Microbial Technology, 11, 411-416.

[22] Azam, T.A., Hiraga, S. and Ishihama, A. (2000) Two Types of Localization of the DNA-Binding Proteins within the Escherichia coli Nucleoid. Genes to Cells, 5, 613-626. http://dx.doi.org/10.1046/j.1365-2443.2000.00350.x

[23] O’Donnell, K. (1993) Fusarium and Its Near Relatives. In: Reynolds, D.R. and Taylor, J.W., Eds., The Fungal Holomarph: Mititic, Meiotic and Pleomorpic Speciation in Fungal Systematic, CAB International, Wallingford, 225-233.

[24] Kurtzman, P. and Robnett, J. (1998) Identification and Phylogeny of Ascomycotous from Analysis of Nuclear Large Subunit (26s) Ribosomal DNA Partial Sequences. U.S. Department of Agriculture, Peoria.

[25] Li, X., Yu, V.Y., Lin, Y., Chomvong, K., Estrela, R., Park, A., Liang, J.M., Znameroski, E.A., Feehan, J., Kim, S.R., Jin, Y.S., Glass, N.L. and Cate, J.H. (2015) Expanding Xylose Metabolism in Yeast for Plant Cell Wall Conversion to Biofuels. eLife, 3, e05896. http://dx.doi.org/10.7554/eLife.05896

[26] Wei, N., Quarterman, J., Kim, S.R., Cate, J.H. and Jin, Y.S. (2013) Enhanced Biofuel Production through Coupled Acetic Acid and Xylose Consumption by Engineered Yeast. Nature Communication, 4, Article No. 2580. http://dx.doi.org/10.1038/ncomms3580

[27] Travassos, L.R. and Cury, A. (1966) Nutrition and Physiology of Thermophilic Yeasts. Anais de Microbiologia, 14, 11-35.

[28] Peng, B., Shen, Y., Li, X., Chen, X., Hou, J. and Bao, X. (2012) Improvement of Xylose Fermentation in RespiratoryDeficient Xylose-Fermenting Saccharomyces cerevisiae. Metabolic Engineering, 14, 9-18. http://dx.doi.org/10.1016/j.ymben.2011.12.001

[29] Laluce, C., Bertolini, M.C., Hernandes, J., Martini, A. and Vaughan Martini, A.E. (1987) Screening Survey for Yeasts That Ferment Sucrose at Relatively High Temperature. Annals of Microbiology, 37, 151-159.

[30] Elliston, A., Wood, I.P., Soucouri, M.J., Tantale, R.J., Dicks, J., Roberts, I.N. and Waldron, K.W. (2015) Methodology for Enabling High-Throughput Simultaneous Saccharification and Fermentation Screening of Yeast Using Solid Biomass as a Substrate. Biotechnology and Biofuels, 8, 2. http://dx.doi.org/10.1186/s13068-014-0181-z

[31] Zhao, X.Q. and Bai, F.W. (2009) Mechanisms of Yeast Stress Tolerance and Its Manipulation for Efficient Fuel Ethanol Production. Journal of Biotechnology, 144, 23-30. http://dx.doi.org/10.1016/j.jbiotec.2009.05.001

[32] Thomas, K.C., Hynes, S.H. and Ingledew, W.M. (2002) Influence of Medium Buffering Capacity on Inhibition of Saccharomyces cerevisiae Growth by Acetic and Lactic Acids. Applied and Environmental Microbiology, 68, 16161623. http://dx.doi.org/10.1128/AEM.68.4.1616-1623.2002

[33] Kumar, S., Dheeran, P., Singh, S.P., Mishra, I.M. and Adhikari, D.K. (2015) Bioprocessing of Bagasse Hydrolysate for Ethanol and Xylitol Production Using Thermotolerant Yeast. Bioprocess and Biosystems Engineering, 38, 39-47. http://dx.doi.org/10.1007/s00449-014-1241-2 